\title{
AZ EURÓPAI VÁLLALAT (SOCIETAS EUROPAEA) KIALAKULÁSA
}

A Societas Europaea olyan nyilvánosan múködô európai részvénytársaság, amely múködésének bizonyos elớirásait, valójában inkább alapításának fố szabályait a nemzetek feletti jellegú közösségi jog hatálya alá helyezik, kivonva e néhány terület szabályozását a nemzeti hatáskör alól. Ez a forma lehetôvé teszi, hogy az Európai Unió több tagállamában jelen lévố vállalatcsoportok csökkentsék vagy elkerüljék a leányvállalataik, fiókjaik, részlegeik múködését befolyásoló tagállami elôírások sokszínúiségéból fakadó korlátokat és költségeket. A megnövelt mozgástérnek köszönhetôen az ilyen cégek uniós szinten optimalizálhatják tagállami határokon átívelő üzleti tevékenységüket és a vállalati felépítésüket. Ez lehetôvé teszi az egységes belsố piac kínálta elméleti elốnyök gyakorlati haszonra váltását. Olyan szervezeti újítás, amely kitágítja az európai dimenziójú cégek mozgásterét és növelheti nemzetközi versenyképességüket, de e kereteket az integráció további bóvítésének és a cégeknek maguknak kell innovatív tartalommal megtölteniük.

\section{Kulcsszavak: európai vállalat, vállalati formák, Európai Unió}

A jelenlegi évtized első felének egyik legfontosabb és sajátos fejleménye a vállalati környezetet, a vállalatalapítás feltételeit és a vállalati formák kialakítását érintő közösségi szintú szabályozásban az európai vállalat (európai részvénytársaság, Societas Europaea, SE) fogalmának tényleges megjelenése, az ilyen típusú vállalati forma lassú, de már érzékelhetô terjedése. A történet, mint általában lenni szokott, a múltban gyökeredzik, és különösen igaz ez a megállapítás a dolgozat tárgyát képező fogalomra. Valójában az integráció több évtizedes fejlődésével összefüggő, lassú, nehézkes, és sokszor megtorpanó jogalkotási folyamat meghatározó szakasza zárult le 2001 októberében, amikor megszületett az európai vállalat alapítását szabályozó alaprendelet és az ehhez kapcsolódó irányelv. Az európai vállalatot, mint új, sajátos uniós jogi kategóriát érintő szabályozás két pillére, a Tanács 2157/2001 számú rendelete ${ }^{1}$ és a 2001/ 86/EK számú tanácsi irányelv ${ }^{2}$ tehát megnyitotta az utat az európai vállalat múködéséhez. Ezzel létrejöttek a szükséges, és a jelenlegi viszonyok között elégségesnek tartható jogi keretek, hiszen néhány, ha nem is nagyszámú, uniós vállalat már döntött e jogi gazdálkodási forma alkalmazásáról. Nem mondhatjuk azonban, hogy ezzel a történet véget is ér, hiszen az adott szabályozási elemek és a nyomukban megjelenő európai vállalatok tapasz- talatai nyilván célszerúvé teszik a jogalkotás jövőbeni továbbvitelét, finomítását, esetleg kiterjesztését is. A folyamat kiinduló keretei azonban már adottak.

A dolgozat azt a célt túzi ki, hogy röviden bemutassa az európai vállalat fogalmát a létrejöttét magyarázó gazdasági és szabályozási törekvések tükrében. Arra keresünk választ, hogy milyen tényezốk eredményezték e forma kialakulását és tartják indokoltnak a létét. A tanulmány áttekinti az említett két jogszabály megszületéséhez vezetô hosszú történeti út legfontosabb lépéseit és vitás kérdéseit. Magyarázatot igyekszik találni arra, hogy milyen alapvető motivációk, az európai vállalathoz füzött milyen várakozások tartották mozgásban és napirenden ezt a folyamatot. Végül rövid értékelést próbálunk megfogalmazni arról, hogy vajon milyen mértékben képes jelenleg beteljesíteni e vállalati kategória a hozzá kapcsolódó elvárásokat.

\section{Az európai vállalat és megjelenésének okai}

A Societas Europaea olyan nyilvánosan múködô európai részvénytársaság, amely múködésének bizonyos előírásait, valójában inkább alapításának fó szabályait, a nemzetek feletti jellegú közösségi jog hatálya alá helyezi, kivonva az e meghatározott területek szabá- 
lyozását a nemzeti hatáskör alól, az egyébként igen változatos nemzeti szabályok hatásköréból. A Societes Europaea választható, nem kötelezô, a nemzeti szintû vállalati szabályozás alternatívájaként kínálkozó forma, elsôsorban olyan uniós cégek számára, amelyek a tevékenységüket nem lokálisan, szúk regionális keretek között, hanem közösségi vagy azon túlmutató léptékben szervezik.

Ez a forma lehetôvé teszi, hogy az Európai Unió több tagállamában jelen lévố vállalatcsoportok csökkentsék vagy elkerüljék a leányvállalataik, fiókjaik, részlegeik múködését befolyásoló tagállami elő́rások sokszínúségéból fakadó korlátokat és költségeket. Az így létrejövő cég - ha nem is teljes egészében, de jelentős mértékben - a közösségi jog alapján létrehozott, szupranacionális vállalattá válik, ami megnövelt mozgásteret, autonómiát kölcsönöz számára a tagállamok nemzeti joga alapján múködő multinacionális formához képest. A megnövelt mozgástérnek köszönhetôen az ilyen cégek uniós szinten optimalizálhatják tagállami határokon átívelő üzleti tevékenységüket és a vállalati felépítésüket. Ez lehetôvé teszi az egységes belső piac kínálta elméleti előnyök gyakorlati haszonra váltását.

Joggal merülhet fel a kérdés, hogy mennyiben jelent az európai vállalat olyan vonzó többletlehetôséget a kizárólag a nemzeti szabályozásnak alárendelt, akár multinacionális, de mégis „hagyományos” vállalati formához képest. Miért érhette meg több évtizeden keresztül erőfeszítéseket tenni a Societas Europaea érdekében?

A válasz több tekintetben is az európai integráció eddigi vívmányainak felemásságában, különösen az egységes piac bizonyos területeken korlátozott megvalósulásában keresendő. Tekintsünk át az ebből fakadó néhány problémát részletesebben is.

$\mathrm{Az}$ egységes piac elméletileg egységes, vagy legalábbis egymással nem élesen konfrontálódó elvek és szabályok szerint múködő gazdasági teret volt hivatott teremteni. Ez bizonyos területeken nagyjából meg is valósult, a vállalatok múködését alapvetôen befolyásoló néhány szegmensben azonban - a tagállami sajátosságok fennmaradása folytán, és az ezekhez kapcsolódó tagállami érdekviszonyok miatt - nem teljesen sikerült egységes gazdasági és szabályozási térré formálni a közösségi piacot.

A vállalati törvények terén az Európai Unióban két alapvető megközelítés körvonalazódott az elmúlt évtizedekben. Az egyik megközelítés lényege, hogy mély harmonizációt indítsanak el a tagállamok nemzeti jogszabályai között. Ez a folyamat hozott bizonyos eredményeket, de harminc-negyven évre visszatekintve ezek az erőfeszítések erősen korlátozott sikernek értékelhetóek. A tagállamok nem lelkesedtek azért, hogy a náluk múködô cégekre idegen hagyományokon alapuló vállalatirányítási és szabályozási rendszert eróltessenek, ami a harmonizációs megközelítés következménye lett volna. Bebizonyosodott, hogy nehéz harmonizálni a nemzeti jogi és gazdasági hagyományokban gyökeredző eltérô szabályozási rendszereket, különösen olyan területeken, mint a vállalati szervezet, az adózás, a munkavállalói részvétel és beleszólás stb. A nemzeti attitüdök lényegében legyứrték a harmonizációs törekvéseket.

A másik megfigyelhetô megközelítés azt szorgalmazta, hogy közösségi szinten jöjjön létre a vállalati törvénykezés magját alkotó uniós szabályegyüttes, ami együtt tud élni a tagállamok egyéni vállalati törvényrendszerével. Ebben a helyzetben a cégeknek választási lehetőségük adódna, hogy egészében a közösségi, vagy kizárólag a nemzeti szabályozási keretek között tevékenykedjenek. Ez a megközelítés sem hozott azonban lényegesen nagyobb előrelépést az elsôhöz képest. A cégek attól tartottak, hogy az egységes közösségi keretek, amit a második megközelítés vont volna maga után, nem bizonyulnak hozzáilleszthetőnek a saját vállalati hagyományaikhoz, amely versenyhátrányba hozza a hazai cégeket más tagállamok vállalataihoz képest.

Érdekes megfigyelni, miként „,hadakozott”, esetenként keveredett egymással az elóbb említett két elképzelés az idốk folyamán.

A második típusú, egy radikálisnak mondható egységesítő álláspont tükröződött az európai részvénytársasággal kapcsolatos kezdeti, az 1960-as években megfogalmazódó tervekben, elsôsorban az Európai Bizottság javaslataiban. Az Európai Bizottság abban a „közösségi eufóriával" jellemezhetô időszakban azt a nagyon ambiciózus víziót dolgozta ki, amely szerint a közösségben létrejönne egy szupranacionális, a tagállamok nemzeti jogrendjeitól minden tekintetben független vállalati forma, amely egy mindenre kiterjedő közösségi vállalati törvénykezés keretei között múködhetne. Hosszú és terméketlen viták után vált nyilvánvalóvá, hogy egy ilyen konstrukció nem reális és kivitelezhetetlen. A Societas Europaea mostani formájában meglehetôsen távol áll attól az európai vállalattól, amely e formáció ötletének felmerülésekor körvonalazódott.

Az 1990-es évtizedben az elsóként említett, a harmonizáció következetes végigvitelén alapuló megközelítés nyert teret. Ez egyrészt az egységes piac tervéhez kapcsolódó harmonizációs logika felerôsödésével függ össze. Másrészt ezekre az évekre vált uralkodóvá, sốt „divatossá” a szubszidiaritás gondolata és eszménye, amely számos területen óhatatlanul felvetette a közösségi és tagállami jogkörök közötti viszony kérdését, 
esetleg annak átgondolását is. Megerôsödtek a kételyek, hogy van-e, és milyen keretek között van létjogosultsága a közösségi fellépésnek a vállalati törvénykezés területén. A közösségi szabályozás és a harmonizáció melletti érvelés, elsôsorban megint az Európai Bizottság részéról, azon alapult, hogy az integrált egységes piacon célszerú bizonyos közös szabályok érvényesítése, másrészt az egységes piacon fennmaradó jogi akadályok leküzdése érdekében szükséges a megerôsített harmonizáció. Ennek az évtizednek a vitái azt bizonyították be, hogy a vállalati szabályozás harmonizáción alapuló megközelítésének következetes megvalósítását sem készek elfogadni a tagállamok, mégpedig valószínúleg e joganyag szerteágazó, nem harmonizált területekhez is kapcsolódó jellege miatt.

Az európai vállalat kidolgozott szabályozása sajátos kompromisszumos megoldást kínál, habár inkább a második megközelítés, a részlegesen egységes szabályok irányában megtett elsô, korlátozott lépésnek tekinthető. ${ }^{3}$ Miközben egységes szabályokat állapít meg az európai vállalatra, ezek a szabályok közel sem fogják át a vállalatok teljes tevékenységét, a meglévő „lyukakat" a Societas Europaea bejegyzése szerinti tagállam jogszabályai tölthetik ki, egyes területeken pedig annak a tagállamnak a szabályai, ahol a vállalatcsoport tagjai múködnek.

Sajátos nehézséget vetett fel az uniós országok vállalati jogában a bejegyzés és az áttelepülés problémája, vagyis leegyszerúsítve az, hogy honnan származónak, milyen ,nemzetiségúnek” kell tekinteni egy vállalatot. Ennek a kérdésnek két vetülete van. Az egyik a letelepedés szabályozásának sajátosságaihoz kapcsolódik. A Római Szerződés a természetes személyek letelepedését közösségi szinten és egyértelmúen szabályozza. A természetes személy egyik országból egy másik tagállamba történố áttelepülése az említett szerződésból fakadó közösségi szinten garantált szabadság. A letelepedés és a tagállamok közötti áttelepülés szabadsága és zökkenőmentessége a jogi személyek esetében legalább ennyire jelentős, hiszen egy cég számára életbevágó, miként képes nemzeti határokon átnyúló üzleti tevékenységet folytatni, mennyire tud rugalmasan mozogni az Európai Unió piacán. A természetes személyekkel ellentétben azonban a jogi személyek bejegyzett központjának áthelyezése a nemzeti jogrendek keretében szabályozódik. Mint korábban említettuik, az ebben irányadó tagállami szabályok közel sem harmonizáltak, sokszínúségük rendkívül megnehezíti az áttelepülést.

Azonkívül, hogy a jogi személyek áttelepülését a tagállamok szintjén szabályozzák az Európai Unióban, a dolgot bonyolítja, hogy ezek a tagállamok a vállalatok származására nézve két eltérô doktrínát alkal- maznak, ezért a több országban is múködő vállalatok eltérô megközelítéssel találkoznak. Az egyik iskola képviselói, ide tartozik például az Egyesült Királyság és Dánia, az úgynevezett bejegyzés elvét (incorporation doctrine) alkalmazzák egy vállalat származására nézve. E gyakorlat értelmében a vállalat múködésére irányadó jog azon országnak a joga, ahol a céget bejegyezték. Más országok ugyanebben a helyzetben az úgynevezett tényleges székhely elvét (the real seat theory) alkalmazzák. Ezek általában a kontinentális országok. Ennek az elméletnek az értelmében a vállalat múködésére annak az országnak a szabályai érvényesek, ahol a cég irányítóközpontja, illetve a központi ügyintézés (head office) van. ${ }^{4}$

Ezeket a szabályozásbeli eltéréseket az európai vállalat nagyrészt képes kiküszöbölni. Azáltal, hogy a Societas Europaea esetében a bejegyzett székhely országának a joga érvényesül, az európai vállalat kiszabadul e két említett eltérő megközelítés fogságából, egyértelmúbb alapokra helyeződik az alkalmazni szükséges jogrend kérdése. Az említett tanácsi rendelet egyértelmúen kimondja, hogy a Societas Europaea alapításakor a székhelyelv érvényesül, és ezt a vállalatot minden uniós tagállamban úgy kell tekinteni, mintha a székhelye szerinti tagállam joga szerint alapított, nyilvánosan múködő részvénytársaság lenne. Az európai vállalat alapítására vonatkozó meghatározó szabályokat a tanácsi rendelet rögzíti, kiegészítve a székhely szerinti tagállami rendelkezésekkel. Ezzel párhuzamosan az áttelepülés szabályozása is kikerül a nemzeti jogrendek keretéből, és közösségi szinten határozódik meg.

A vállalati múködést befolyásoló következő területen, a szervezeti felépítésben, is tetten érhetô a nyilvános részvénytársaságokra vonatkozó nemzeti szabályozás gazdasági és jogi hagyományokra visszavezethetô eltérése, a harmonizáció hiánya. A részvénytársaság legfő́bb irányító szerve a részvényesek közgyúlése, a további szervezeti egységek felállítása azonban annak a függvényében alakulhat, hogy egy tagállam hagyományokon alapuló előírásai mit tesznek szükségessé. Az uniós tagállamok körében két eltérő típusú irányítási szervezeti felépítés fordul elő. ${ }^{5}$

$\mathrm{Az}$ egyik az úgynevezett egyszintú vagy monista rendszer (one-tier system), a másik a kétszintú vagy dualista rendszer (two-tier system). Az elsốt az angolszász hagyományokat követô országok - például az Egyesült Királyság és Írország - alkalmazzák, a másodikat a kontinentális jogból kiinduló államok, például Németország, Ausztria, Hollandia és Olaszország, de ide tartozik Magyarország is. Az egyszintú rendszerben az operatív irányítást egyedül az igazgatótanács (administrative board) végzi. A kétszintú rendszerben 
a cégvezetés az irányító szerv feladata, ezt pedig a felügyeleti szerv (supervisory board) felügyeli, amely nem vesz részt a részvénytársaság irányításában. Anélkül, hogy e rendszerek jogi és múködésbeli részleteibe belemennénk, csak annak illusztrálásaként említettük, hogy amennyiben egy vállalat áthelyezi székhelyét egy másik tagállamba, ahol eltérô irányítási struktúra érvényesül, szembe kell néznie a hagyományaiba és szerkezetébe nem illeszkedő előírásokkal. Mindez alapvetően megnehezíti mozgékonyságát, a tagállamok közötti mozgásból fakadó elônyök kihasználását az egységes piac keretei között is. Így nagyfokú merevség érvényesül az adott vállalat számára, ami akadályozza az üzleti tevékenység optimalizálását.

Az egységes piacból adódó elônyök tényleges kihasználásához célszerú oldani vagy akár megszüntetni ezt a merevséget. A Societas Europaea alkalmas megoldásként kínálkozik erre, mivel a közösségi szabályozás a tanácsi rendeletben e vállalatot kivonja a nemzeti szabályok keretei közül, és lehetôvé teszi, hogy a részvényesek - függetlenül a bejegyzés szerinti ország előírásaitól - maguk válasszák meg a vállalati irányítás struktúráját. Ezáltal megszabadulnak a belső irányítás költséges és sokszor nehézkes átalakításának kényszerétól.

Az Európai Unióban az utóbbi néhány évben napirenden és kialakulóban vannak a vállalatokat érintô szabályozás átalakítására, modernizálására irányuló törekvések. Az Európai Bizottság megfogalmazta a változások alapvetố irányait és motiváló tényezőit. Ezek között elsố helyen az egységes piac elvi adottságainak gyakorlati kihasználása szerepel. Olyan jogi mechanizmusok kialakítására törekszik a bizottság a tagállamokkal folytatott vitákban, amelyek elősegítik a letelepedés és a határokon átnyúló tevékenység erősítését, az uniós cégek határok feletti mozgékonyságát. Ehhez a célhoz szorosan kapcsolódik a tókepiacok szorosabb integrálása, amely aktivizálhatja e piacok szereplőit, a lehetőségekhez és a szándékokhoz igazodó egyszerúsítésekhez, és talán az eddigieknél nagyobb egységesítéshez vezethet, a társaságok részére koherensebb, dinamikusabb, és az igényeknek jobban megfelelő közösségi jogi kereteket eredményezhet.

E folyamatra hatással van az Európai Unió kibővülése is. Az új tagállamok belépése növelte, illetve növeli a vállalatokra vonatkozó szabályozás sokszínúségét. A bővítés tovább erôsíti a közösségen belüli vállalati tevékenység jogbiztonsága iránti igényt, a vállalati jogokra vonatkozó acquis communautaire modernizálása elősegítheti az új tagállamok korszerú és versenyképes piacgazdaságokként való betagozódását az egységes piacba.

A gazdasági élet szereplőiben az utóbbi évek eseményei kapcsán felerősödött az igény a vállalati tevékeny- ség és a tớkepiac jogbiztonsága, a nyilvánosan múködő vállalatok áttekinthetősége, másképpen fogalmazva erôsebb közösségi fegyelem érvényesítése iránt.

Ezekbe a törekvésekbe logikusan és célszerúen illeszkedik az európai vállalat koncepciójának szabályokba foglalása. A vállalati joganyag megújításának egyik kezdeti, részleges lépését jelentheti tehát a Societas Europaea, amely kompromisszumaival együtt is képes választ adni az egységes piac kihívásainak egy részére. Ez alapvetôen hozzájárult e vállalati konstrukció létrejöttéhez.

\section{A Societas Europaea kialakulásának folyamata}

Az európai integráció kialakulása és előrehaladása folyamatosan napirenden tartotta a kereskedelem, a tôkeáramlás, a szolgáltatások nyújtásának szabadságát, valamint a fokozatosan egységesülő közösségi gazdasági tér keretei között megvalósítható üzleti tevékenység szabadságát elősegítő intézkedéseket. Ebbe az integrációs folyamatba illeszkedik az európai vállalat kialakításnak hosszú története az ötlet megszületésétól a jogszabályi háttér megteremtéséig. ${ }^{6}$

Az európai vállalat ötlete szinte egyidôsnek mondható magával az Európai Gazdasági Közösséggel. Először 1959-ben merült fel a francia közjegyzók egyik kongresszusán. Az ilyen vállalati forma kialakítását felkarolta a szakma nagy tekintélyének számító Sanders professzor, és az ötlet elkezdett terjedni az akadémiai, vállalkozói körökben, de reagálásra késztette a Közösséget is. Néhány év elteltével, 1966-ban az Európai Bizottság elsô intézményes lépésként kiadott egy memorandumot az európai kereskedelmi vállalat megalapításáról. Ezzel egyidejúleg Sanders professzor vezetésével szakértói csoport alakult, hogy megvizsgálja egy, a tagállamok összességében azonos jogi alapon múködtetett vállalat potenciális elônyeit. A munkacsoport a lehetséges elónyök mellett kénytelen volt szembesülni azokkal a nehézségekkel és azonosítani azokat, amelyek kiküszöbölését célozták a következó évek erófeszítései.

A gondolat azonban már akkora teret kapott, hogy a nehézségekre hivatkozva nem lehetett félretenni az ötletet. Beindult a közösségi mechanizmus, amelynek eredményeként az Európai Bizottság 1970-ben kiadott egy előzetes rendeletjavaslatot, amelyet két évre rá elfogadott a Gazdasági és Szociális Bizottság és kisebb, a munkavállalókat érintố kiegészítésekkel egyetértett a javaslattal az Európai Parlament is. Ezek után 1975ben az Európai Bizottság letette az asztalra az egységes, nemzetek feletti szabályozásra irányuló, az elôzó fejezetben egységesítő megközelítésként bemutatott 
szemléletet tükrözó rendeletjavaslatát. A tagállamok azonban nem tudtak konszenzusra jutni, mégpedig alapvetốen a nemzetek feletti szabályozással szembeni, ugyancsak az előzó fejezetben említett tartózkodó és ellenérzésekkel teli magatartásuk miatt. Ennek következtében a folyamat megtorpant, a javaslat hosszú időre lekerült a napirendról.

Az Európai Bizottság csak bó egy évtized elteltével tért vissza erre a kérdésre, amikor 1988-ban egy memorandumban felhívta a tagállamokat az álláspontok újrafogalmazására és új javaslatok megtételére. A problémák megoldására irányuló közösségi, pontosabban bizottsági aktivitás megélénkülése szorosan összefügg az ebben az időszakban a figyelem középpontjában lévő egységes belsố piaci programmal. Az egységes piac kialakulásának folyamata ugyanis beleütközött a határokon átnyúló gazdasági tevékenységet akadályozó vállalati jogi elégtelenségekbe, a nemzeti szabályok dominanciájából adódó ellentmondásokba, az áttekinthetetlen szabályozási háttérbe. A bizottsági memorandum kitért a megelóző évtizedben már egyik problémaként körvonalazódó kérdés, a munkavállalói részvétel megoldásának szükségességére is. Ez utóbbit nem csupán a szociális jogok körébe tartozó, hanem a vállalati múködés lényegét jelentô kérdésként fogta fel.

A tagállamok többsége egyetértett az európai vállalat gondolatának felélesztésével, habár a munkavállalói részvétel szabályozása néhányuk esetében (például az Egyesült Királyság részéról) ellenállásba ütközött.

A viták eredményeként az Európai Bizottság 1989ben egy új rendelettervezetet dolgozott ki a tanács számára. Ennek újdonsága az volt, hogy a bizottság a munkavállalói részvétel ügyét kivette a tervezett rendelet magját alkotó szabályozás köréből, és egy önálló kiegészító irányelvben fogalmazta meg. Azt azonban hangsúlyozta, hogy az irányelv a rendelet leválaszthatatlan és érdemi kiegészítóje. A bizottság tervezetének és a rendelet-irányelv kettôsségén alapuló javaslatnak a végiggondolására a tagállamoknak megint csak viszonylag hosszabb időre volt szükségük. A közösségi intézmények és a tagállamok együttmúködésének eredményeként a tervezetet újrafogalmazták, és 1992-ben bocsátották az új szövegét a tanács elé. Az 1992-es szöveg kitér, és rugalmas megoldást helyez kilátásba az előző fejezetben említett, a vállalatirányítási struktúrára vonatkozó problémára, azzal, hogy választási lehetôséget hagy az úgynevezett egyszintú és a kétszintú vállalati szerkezet között.

A tagállamok egymás közötti, valamint az Európai Bizottság rendelettervezetével szembeni véleménykülönbségei néhány évre újból lefékezték a folyamatot. Ez a szünet 1996-ig tartott, amikor az Európai Bizott- ság egy kompromisszumos javaslatot fogalmazott meg. Ennek a lényege és a korábbi tervezetekhez viszonyított újdonsága abban állt, hogy érzékelve a tagállamok bizonyos kérdések nemzetek feletti szabályozásával kapcsolatos ellenállását, a vitás és belátható idôn belül megoldást nem kínáló területek szabályozását (például adózási ügyek, a számviteli rendszerek, a fizetésképtelenség kérdése stb.) a tagállamok nemzeti jogkörében hagyta, sốt kifejezetten hivatkozott a nemzeti szabályok érvényesítésére ezeken a területeken. Habár ez a megoldás szinte áttörésnek érzékelhetố a korábbi bizottsági javaslatokhoz képest, mégsem kapta meg a szükséges tagállami támogatást. Ugyanakkor ebben az idốben a tagállamokban a korábbihoz képest megerôsödött a meggyőződés, hogy az európai vállalat ügyét belátható idő́n belül célszerú lesz megoldani. A vállalati tevékenység uniós szintű kiterjesztését nehezítő akadályok ugyanis pénzben kifejezhetố jelentős kárt okoztak. Ebben az idôben látott napvilágot egy szakértői csoport értékelése, amely kimutatta, hogy e vállalati formáció hiánya az egységes piacon évente harmincmilliárd ecu veszteséget okoz az uniós üzleti szférának. ${ }^{7}$

Valószínúleg nem utolsósorban a gazdasági kényszerek felismerése vezetett oda, hogy a jogalkotás az Európai Bizottság 1996. évi rendelettervezetéból kiindulva megélénkült, és kisebb megtorpanásokkal ugyan, de folytatódott. Felállt egy újabb szakértói csoport, az úgynevezett Davignon-csoport, amelyet azzal a feladattal bíztak meg, hogy a még meglévő nézeteltérések között megtalálja a kompromisszumot. Ezekben az években, 1997 és 1999 között, egyrészt arról folyt a vita, milyen konkrét módokon és milyen technikákkal rendezzék a munkavállalói részvétel „örökzöld” problémáját, milyen intézményes keretek között folytatódjék a vállalatirányítás és a munkavállalók képviselete közötti egyeztetés, miként lesz összeilleszthetố a Societas Europaea által alkalmazott formula a munkavállalók jogait szabályozó uniós jogrenddel. Másrészt megoldást kellett találni a még nyitott kérdésekben, amelyek az európai vállalat megalakításának módozatait érintették, valamint ahhoz kapcsolódtak, hogyan szabályozzák a bejegyzett székhely és a központi ügyintézés (head office) esetleges földrajzi eltérését. Ez utóbbi kérdésben az a döntés született, hogy mindkettônek ugyanabban a tagállamban kell elhelyezkednie. Harmadrészt, vitatott kérdésként szerepelt továbbra is, hogy miként legyenek hivatkozhatóak a nemzeti jogrendek abban az esetben, ha a közösségi rendelet nem szabályoz egy-egy területet, vagy kifejezetten a nemzeti joghoz irányít.

A Davignon-csoport jelentésére támaszkodva, az egymást követő soros elnökségek közvetítő munkájának köszönhetően, 1998 és 1999 között a Societas 
Europaea-t létrehozó alaprendelet körébe tartozó szabályozás körül lényegében teljes egyetértés alakult ki, egyedül Spanyolország fejezte ki különállását. Nehezebben alakult a rendelethez kapcsolódó, a munkavállalói részvételról szóló irányelv sorsa. Végül egy kompromisszumos, legyengítettnek is nevezhetô, a tagállamok álláspontjának és rendszereinek eltérései alapján megengedóbb, a tagállamok számára nagyobb mozgásteret biztosító szöveget kapott az irányelv.

Ezzel nagyrészt elhárultak a szabályozás tartalmi elemeivel összefüggố akadályok, miután mind a tizenöt tagállam, Spanyolországot is beleértve, késznek mutatkozott mind a rendelet, mind a kapcsolódó irányelv elfogadására. Az Európai Tanács nizzai csúcsértekezletén, 2000 decemberében, megszületett a politikai megállapodás is. Ennek köszönhetően a szükséges közösségi intézményi eljárások után, 2001-ben, megszületett a Societas Europaea két pilléren nyugvó jogi alapja.

A rendelet és az irányelv kiadását követően a tagállamok feladata maradt a végrehajtást szolgáló nemzeti jogi háttér kialakítása, hiszen a közösségi szabályozás korábban ismertetett sajátos jellegéból és hatóköréból következôen ebben a nemzeti hatáskör érvényesítésére is szükség van. Ez a közvetlenül alkalmazandó rendelet végrehajtási szabályaira is érvényes. Ebben a folyamatban már a 2004. május elsején teljes jogú taggá vált országok is részt vettek. Meg kell említeni, hogy a vállalati múködés szabályozása szorosan kapcsolódik az egységes piac elveihez és szabályrendszeréhez, ezért a Societas Europaea alapításának lehetósége az Európai Gazdasági Tér (EGT) Európai Unión kívüli résztvevôire is vonatkozik.

Az európai vállalat alapítására és múködésére vonatkozó tanácsi rendelet 2004. október 8-án lépett hatályba. Az azóta eltelt időszakban az unió és az Európai Gazdasági Tér országainak többsége átvette a Societas Europaea szabályozását. A rendelkezésre álló információk alapján 2006 őszéig ebbe a csoportba került Ausztria, Belgium, Csehország, Dánia, Németország, Észtország, Finnország, Franciaország, Magyarország, Lettország, Litvánia, Hollandia, Lengyelország, Portugália, Svédország, Szlovákia, Szlovénia, az Egyesült Királyság, valamint az EGT három Európai Unión kívüli országa. Egyelôre nem fejeződött be a közösségi szabályozás nemzeti jogrendbe való beillesztése (a legújabb rendelkezésre álló adatok szerint) Cipruson, Görögországban, Spanyolországban, Máltán, Olaszországban, Luxemburgban és Írországban. ${ }^{8}$

Az ebben a fejezetben leírtakat összefoglalva megállapítható, hogy rendkívül rögös, ellentmondásos és igen hosszú út vezetett az európai vállalat létrejöttéhez. Az elmondottak alapján ennek magyarázata egyrészt abban rejlik, hogy nem lehetett ezt a szabályozást kizárólag közvetlenül alkalmazandó rendelet formájában meghozni, ennek felismerése, mint láttuk, meglehetôsen késốn született meg. A rendelet olyan tartalmi elemeiról is nehézkesnek bizonyult a kompromisszumra, „közös nevezôre" jutás, amelyek minden tagállam számára elfogadható módon illeszkednek vállalati jogi hagyományaikhoz. Hatványozottan igaz ez a megállapítás az irányelv tartalmi elemeit jelentô, szintén rendkívül érzékeny kérdésekre, amelyek a munkavállalói részvétel szabályozásával függnek össze. A tagállamok nagyon éberek voltak abban a tekintetben, hogy a közösségi szabályozás ne válhasson a nemzeti szabályozás megkerülését szolgáló eszközzé, ahol pedig megengedóbben, lazábban kezelik ezt a szisztémát, igyekeztek kizárni a szigorúbb szabályok „becsempészését” a nemzeti jogrendbe és hagyományokba. Végül magas szintú politikai egyetértésre is szükség volt, amit csak az Európai Tanács nizzai csúcsértekezletén sikerült elérni.

Joggal tehető fel a kérdés, hogy ha ilyen nehezen és lassan született meg a Societas Europaea, milyen mozgatórugók, motivációk játszottak szerepet ebben a folyamatban. Milyen remények és elvárások késztették a közösségi intézményeket, a tagállamokat és az üzleti szférát, hogy hosszú évtizedeken keresztül se hagyják veszni az ügyet, és próbálják - ha komoly kompromiszszumok árán is - áthidalni a nehézségeket.

\section{A Societas Europaea kialakítása mögött meghúzódó motivációk}

Ebben a fejezetben - a teljesség igénye nélkül - áttekintjük azokat a nyilvánvaló vagy rejtettebb motivációkat, amelyek az ilyen típusú vállalati forma szükségességét hangoztató érvelések mögött meghúzódtak az elmúlt években, illetve jelenleg is motiváló tényezóként hatnak az európai vállalat létrehozásában.

\section{Az egységes szabályok}

A korábbiakban több szempontból is próbáltuk megvilágítani a vállalati múködést befolyásoló szabályok nemzetek feletti egységesítésével vagy harmonizációjával összefüggó érdekellentéteket, tagállami tartózkodást. A piaci integrációból, az egységes piac tagadhatatlan kiteljesedéséból természetesen nem következik automatikusan az, hogy csak az európai vállalat formája lehet adekvát az Európai Unió piacán. Az azonban nyilvánvaló, hogy az integráció logikus következménye és jogos igénye, hogy azon cégek számára, amelyek a tagállamok határain átnyúló üzleti tevékenységet végeznek - és a piaci integrációnak köszönhetően ez óhatatlanul természetes jelenséggé válik 
- teremtődjék meg annak a lehetôsége, hogy megmeneküljenek a sokszínú, tagállamonként eltérô szabályozás terhétől. Az európai vállalat egységes, és fóleg egyetlen, szabályegyüttes alkalmazásának lehetôségét nyújtja a cégek több tagállamban tevékenykedő vállalatrészei számára, ha nem is a cég múködésének minden területére érvényes módon, de az alapvetô feltételek esetében, mint például az alapítás, irányítási struktúra stb. tekintetében mindenképpen. Ez tagadhatatlanul egyszerúbbé teszi a cégek életét. Még akkor is, ha a szabályozás nem olyan mértékben vonja ki a nemzeti jog hatálya alól az ilyen cégeket, mint ahogy az európai vállalat ötletének megszületésekor ezt vizionálták - elsősorban az Európai Bizottság.

\section{Költségtakarékosság}

Az európai vállalat formája a szabályok jelentôs részének egyszerúsítése okán a múködési költségek csökkenéséhez vezet. Egy olyan vállalat esetében, amelynek Európa-szerte tevékenykednek leányvállalatai, minden esetben szükséges volt a tagállami szabályoknak megfelelő párhuzamos részlegeket, struktúrákat fenntartania a vállalatcsoporton belül. Az egységes vállalati struktúra alkalmazása jelentôs mértékben csökkentheti az adminisztratív, jogi és egyéb múködési terheket. Ezáltal olyan pénzügyi költségek viselésétól szabadulnak meg, amelyek általában nem sújtják a nemzetközi, vagy kizárólag egyetlen tagállamban múködő versenytársaikat. A Ciampi-bizottság néhány évvel ezelőtti, már korábban is említett becslése szerint e megtakarítás nagysága évente több tízmilliárd euróra rúg. ${ }^{9}$

\section{Szervezeti rugalmasság}

A meghatározó mértékben egységes szabályozási környezet azt is jelenti az európai vállalat számára, hogy megszúnik az eltérô vállalatszervezeti előírásokhoz és hagyományokhoz való alkalmazkodás kényszere. A Societas Europaea a saját döntése folytán választhatja a tagállamokban meghonosodott egyszintú vagy kétszintú szervezeti struktúra bármelyikét, a saját hagyományaihoz, érdekeihez és a vállalati optimumához igazodva. Nincs rákényszerülve, hogy saját szervezetén belül kombinálja a kétféle struktúrát és az azzal összefüggó irányítási kultúrát. Ez különösen azon vállalatok életét könnyíti meg, amelyek leányvállalatai eltérő szisztémát alkalmazó tagállamokban honosak. Az irányítási struktúra hatékonysága és a vállalat kultúrájához igazodó volta nyilvánvalóan a versenyképességét is meghatározó elem.

Az elmondottakkal kapcsolatban két lehetséges tovagyưrüző hatás is körvonalazódik abból, hogy az egyik típusú rendszert alkalmazó országban megjelenik a má- sik típus szerint múködố gazdasági társaság. Az egyik, hogy a jövőben nem zárható ki egyfajta konvergencia a két rendszer között. A másik, hogy egyre inkább elmosódhat a két rendszer közötti merev elkülönültség. Már ma is van néhány, ha nem is sok tagállam, ahol mindkét rendszer szerint múködhetnek társaságok, és nem csupán európai vállalat formájában. Ezt a spanyol, a francia és a portugál jogrend is lehetôvé teszi. A Societas Europaea-nek az osztrák jogrendbe való beágyazása során ott is felmerült a gondolat, hogy nemcsak az európai vállalat számára nyitják meg az irányítási struktúra szabad megválasztásának lehetôségét. ${ }^{10}$

\section{A határokon keresztüli mozgás szabadsága}

$\mathrm{Az}$ európai vállalat megalakításához füződő motivációk körében az elmúlt években mindig az egyik leghangsúlyosabb volt, hogy ez a vállalati forma megkönynyíti a tagállamok közötti mozgást, áttelepülést. Abban az esetben, ha egy cég úgy dönt, hogy kivonul az egyik tagállamból, és a székhelyét áthelyezi egy másikba, egy hosszadalmas és költséges eljáráson kell végigmennie, fel kell számolnia a céget az eredeti országban, és új vállalatot kell alapítani a választott másik tagállamban. A Societas Europaea ezt a problémás folyamatot kiküszöböli, és reálisan kihasználható egységes gazdasági térséggé változtatja az Európai Uniót a stratégiájukat a közösségi térben megvalósító vállalatok számára. A társaságok mozgási lehetőségének jelentôs kiterjedése az európai vállalat mellett szóló egyik legnyomósabb érv ma is. ${ }^{11}$

E lehetôségnek lehet olyan hatása, hogy a vállalatok hirtelen és gyorsan elkezdenek mozogni a tagállamok között, ahogy éppen kedvezóbbnek ítélik meg egyik vagy másik ország vállalati jogi környezetét. Több spekuláció is született e „vándorlás” várható mértékéről. Eddig masszív mozgás nem volt tapasztalható, de a jövőben nem zárható ki, hogy a multinacionális vállalatok egy része igyekszik majd kihasználni ezt a lehetôséget. Érdekes hírként szerepelt, hogy a Societas Europaea szabályainak hatályba lépésével szinte egyidejúleg a General Motors fontolóra vette európai székhelyének áthelyezését Svájcból Belgiumba és SE-ként való bejegyzését. ${ }^{12}$

\section{A határon átnyúló egyesülés}

A határokon keresztül történó egyesülés (crossborder merger) a Societas Europaea alapításának egyik módja. Az európai vállalat megjelenése elốtt a tagállamok cégeinek nem volt meg a lehetósége a közvetlen egyesülésre egy másik tagállam cégével. A Societas Europaea kínálta egyik fontos lehetőség, hogy ezt a formát választó cégek ezt a tranzakciót nehézségek nélkül 
megtehetik. Ez az elóny azonban relativizálódott azáltal, hogy az Európai Unióban 2005-ben megszületett a Tizedik Vállalati Jogi Irányelv, amely kiküszöbölte a egyesülés korábbi merevebb szabályozásának hátrányait. Az említett irányelv azonban várhatóan csak 2007 végén léphet hatályba, addig viszont az ilyen tranzakciókhoz egyedül az európai vállalat formulája szolgál jogi alapul. Egyébként a vállalati irányelv szövege nagyban támaszkodik az európai vállalatról szóló rendeletre.

\section{Európai arculat}

A Societas Europaea formát választó cégek megnevezésükben is viselik a SE megjelölést, ami önmagában is azt képes sugallni, hogy nem egy „egyszerư” multinacionális vállalatról van szó, nem is az egyikról a sok-sok ezer, tagállamokszerte múködő cégbőll. A megjelölésnek és az elnevezésnek tehát van egy pótlólagos üzenete, nevezetesen, hogy a szóban forgó cég valami más kategóriát, esetleg minőséget jelent, talán a nemzeti jogrendektől való függetlenségük folytán a relatíve nagyobb tevékenységi szabadság is társítható hozzá. A cég megnevezése reklámértékúen utal arra, hogy tevékenysége kontinentális léptékú, bizonyos nagyságot és erốt sugallhat. Emellett egyfajta identitás-jelölésnek is felfogható. Tegyük hozzá azért az igazság kedvéért, hogy mindez csak abban a mértékben érvényesülhet, amennyire az emberekben az „európai” kifejezés és a vállalat szabadsága pozitív értékítéletet vált ki. Ha azonban ez így van, a Societas Europaea fogadtatása egy-egy tagállamban kedvezóbb lehet, mintha egy vagy több másik tagállam vállalatáról lenne szó. Ezzel hozzájárulhat az államok közötti pszichológiai korlátok leépítéséhez.

A Societas Europaea e tulajdonsága és üzenete ugyan lehetett mozgósítóerố azok számára, akik az ilyen vállalati forma megteremtéséért tevékenykedtek, automatikusan azonban nem feltétlen jelent tényleges előnyt. A gyakorlat fogja megmutatni, hogy ez az inkább pszichológiai és optikai arculati elem konvertálható lesz-e gazdasági haszonra.

\section{A befektetés biztonsága és a tókebevonás}

Ez a motiváló tényező és elôny az előzôhöz hasonlóan jelenleg még inkább csak spekulatív lehetôség. Elméletileg a nemzeti jogrenden felülemelkedő, semlegesebb jelleg nagyobb biztonságot nyújthat a tagállamok esetleges nemzeti protekcionista akcióikkal szemben, a nemzetek feletti jelleg csökkenti a szabályozás eltéréseiból fakadó bizonytalanságot.

$\mathrm{Az}$ európai vállalatról szóló viták során e forma mellett olyan érv is megfogalmazódott, hogy az ilyen cégek tókevonzó képessége nagyobb lehet a hagyományos keretek között múködő multinacionális vállalatokhoz képest. Ez a szempont legtöbbször az Európai Bizottság anyagaiban, vagy a közösségi elkötelezettségú tájékoztatókban fordult elô. ${ }^{13} \mathrm{Az}$ érvelés szerint az európai léptékú infrastrukturális beruházások, közlekedési és távközlési projektek finanszírozására az európai vállalat könnyebben vonhat be tôkét és vonzhat befektetốket, mint a nemzeti vállalatok. Ennek a szempontnak a gyakorlati beigazolódására egyelôre az eltelt idő még nem elegendő.

\section{Adóügyek}

A Societas Europaea létrehozásának folyamán az ilyen vállalat adóztatásának mechanizmusa az egyik leginkább problematikus kérdés volt. Az Európai Bizottságnak az 1970-es évtizedben megfogalmazott első rendelettervezete meglehetősen kiterjedt adóügyi szabályozást tartalmazott. A tagállamok ellenállása folytán a bizottság 1989. évi javaslata lényegesen visszafogottabb ambíciók talaján az adóztatással kapcsolatban már csak egyetlen, a bejegyzett székhelyet érintő szabályt javasolt belevenni a rendeletbe. A rendelet végsố formába öntését megelőző, az 1990-es évtized végén lefolytatott viták eredményeként ez az egyetlen rendelkezés is kikerült a szövegboól, mivel a tagállamok ezt külön kívánták kezelni. A Societas Europaea rendelete tehát az adókra vonatkozó szabályok nélkül látott napvilágot, ezt a kérdést a nemzeti kompetenciák körébe helyezi.

A közös rendelkezések hiánya és a nemzeti adórendszerek jelentôs eltérése azt eredményezi, hogy a tagállamok adószempontból nemzeti társaságként kezelik az európai vállalatot, következésképpen e vállalatcsoport tagjaira a megfelelő tagállam elôírásai vonatkoznak. Mivel az Európai Unióban és az Európai Gazdasági Térben nincs tényleges adóharmonizáció, ez a helyzet a bonyolultságával és áttekinthetetlenségével nem fejt ki attraktív erốt az európai vállalatok alapításához, sốt inkább akadályként, hátrányként szokták említeni.

Ez az anomália azonban a jövőben akár előnnyé is válhat. Megfigyelhetô, hogy a tagállamok egy részében - például Belgiumban - körvonalazódnak olyan törekvések, amelyek nemzeti keretek között speciális adószabályok felállítását szorgalmazzák. Igaz, eddig ez még nem vált valósággá. Ha azonban megtörténne, hogy a tagállamok vagy egy részük adózási szempontból a Societas Europaea számára speciális szabályokat léptetnének életbe, például az ilyen vállalatok bejegyzett székhelyére, akkor az európai vállalat válogathatna székhelyének bejegyzésekor a legkedvezóbb feltételeket kínáló tagállamok között. Tudvalevőleg, az európai vállalat könnyen képes áthelyezni a székhelyét egy 
másik országba, ezért gyorsan reagálhat a tagállamok SE-székhelyre vonatkozó adószabályainak változásaira és áttelepülhet oda, ahol számára legelőnyösebb. Ez egyfajta versenyt indíthat el a tagállamok között, ami - legalábbis a Societas Europaea szempontjából - előnyt jelenthet. ${ }^{14}$

\section{Összefoglalás}

A Societas Europaea kialakulásának folyamata és jogszabályi alapjai a rendkívül divergens tagállami érdekek és vállalatszabályozási hagyományok összetett kompromisszuma. A jelenlegi európai vállalatok, az európai részvénytársaságok meglehetôsen távol állnak attól a víziótól, amit a gondolat megszületésekor célul tûztek ki. Ennek ellenére ez a vállalati forma ténylegesen választható, gyakorlati gazdasági előnyöket is felmutatni képes alternatíva az európai dimenzióban gondolkodó és az egységes piacon tevékenykedő cégek számára. Végső soron az európai integráció mélyüléséhez, az európai szabályok közeledéséhez és bizonyos mértékú egységesüléséhez logikusan kapcsolódó, adekvát formula.

Hangsúlyozni szükséges emellett, hogy az európai részvénytársaság mint cégforma - és nem csak a kompromisszumai és tagadhatatlan hiányosságai miatt - önmagában nem mindenható garancia az európai vállalatok Európai Unión belüli és világgazdasági versenyben való sikeres szerepléséhez. Olyan szervezeti újítás, amely ebben a versenyben kitágítja az európai dimenziójú cégek mozgásterét, de e kereteket az integráció további mélyítésének és a cégeknek maguknak kell innovatív tartalommal megtölteniük.

Az európai vállalati jogban az európai részvénytársaság kialakítása bizonyos mértékben felerôsítette az egységesítés logikáját, kikövezte az utat a nem részvénytársasági formában múködő vállalatok, gazdasági egyesületek, társaságok, gazdasági szövetkezetek hasonló európai dimenziójához. Egyre erôsebb a törekvés, hogy a Societas Europaea modelljéhez hasonló jogi kereteket teremtsenek a kis- és közepes vállalatok számára. Az úgynevezett European Private Company szükségessége több tagállam üzleti szférájának elképzeléseiben és az uniós szintú érdekképviseleti szervezetek javaslataiban is megjelent. Létjogosultsága abban áll, hogy e kisebb vállalatok adottságaihoz és igényeihez szabná a valójában a jóval nagyobb cégekre méretezett SE-szabályokat. E téren még 2002-ben fogalmazta meg elsô javaslatát az Európai Bizottság által felkért, az európai vállalati jog modernizációjával foglalkozó, Jaap Winter vezette szakértói csoport. A jogi szakértớk jelentésükben távlati célként azt is hangsúlyozzák, hogy a szövetkezeti formában múködő cégek esetében is célszerú uniós szintú keretszabályokat alkotni, amelyek idôvel lehetôvé tennék a Societas Corporativa Europaea kialakulását. ${ }^{15} \mathrm{E}$ folyamatban szimbolikus és meghatározó lehet a Societas Europaea sikere a következố időszakban. Hogy ez bekövetkezik-e, arra a jövő adhat választ. Mint ahogy arra is, vajon képes lesz-e az európai vállalat pótlólagos impulzusokkal szolgálni az Európai Unió belsố piacának további egységesítéséhez.

\section{Lábjegyzet}

1 Council Regulation (EC) 2001/2157, 8.10.2001

2 Council Directive 2001/86/EC, 8.10.2001

3 Teare (2006)

${ }^{4}$ Chetcuti Cauchi (2001a)

5 Részletesen lásd: Herpai Gyuláné (2005), 81-82. old.

${ }^{6}$ A történeti leírás nagyban támaszkodik Chetcuti Cauchi (2001b) áttekintésére

${ }^{7}$ A szakértői bizottságot a volt olasz elnök, Carlo Ciampi vezette.

${ }^{8}$ Van Gerven-Janssens (2006)

9 Zrzavecky (2006)

${ }^{10}$ Reemers-Schultze Enden (2004)

${ }^{11}$ Cafritz - Gillespie (2004)

12 Erról ad hírt a Gibson, Dunn \& Crutcher ügyvédi iroda (2004)

${ }^{13}$ Lásd például Bolkenstein (2002)

14 Van Gerven - Janssens (2006)

${ }^{15}$ Report of the High Level Group of Company Law Experts (2002)

\section{Felhasznált irodalom}

Bolkenstein, Frits (2002): Speech by Frits Bolkenstein, The new European Company: opportunity in diversity, Address to Conference at the University of Leiden, Leiden, 29 November, European Commission, Press Releases, SPEECH/02/598

Cafritz, Eric - Gillespie, James (2004): The Societas Europaea, Thirty Years Later, Fried, Frank, Harris, Shriver \& Jacobson LLP, Client Memorandum, 9 December, http://www.ffhsj.com/cmemos/041209_societas\%20europeae.pdf

Chetcuti Cauchi, Maria (2001a): The European Company Statute: Freedom of Movement of Societas Europaea,

http://www.chetcuticauchi.com/mcc/research/freedom-ofmovement-european-company.htm

Chetcuti Cauchi, Maria (2001b): The European Company Statute: The Societas Europaea (European Company) as a New Corporate Vehicle

http://www.chetcuticauchi.com/mcc/research/europeancompany-statute-1.htm

Council Directive 2001/86/EC, October 8, 2001, OJEC 10.11.2001, L 294/22. 
Council Regulation (EC) No.215/2001, October 8, 2001, OJEC 10.11.2001, L 294/1.

Germany Paves the Road to European Stock Corporation, Gibson, Dunn \& Crutcher LLP, 2004, http://www. gibsondunn.com/practices/publications/detail/id/766/ ?publtemld $=7661$

Herpai Gyuláné (2005): Európai Részvénytársaság: Societas Europaea, BGF Külkereskedelmi Főiskolai Kar, EU Working Papers, 2. szám

Reemers, Jürgen - Schultze Enden, Hanno, P. (2004): A New Vehicle for European Cross-Border Transactions: The European Company (Societas europaea), Jones Day Commentaries, December, http://www.jonesday.com/ pubs/pubs_detail.aspx?publD $=\mathrm{S} 1502$

Cikk beérkezett: 2007. 3. hó

Lektori vélemény alapján átdolgozva: 2007. 6. hó
Report of the High Level Group of Company Law on Modern Regulatory Framework of Company Law in Europe, Brussels, 4 November 2002 http://ec.europa.eu/internal_ market/company/docs/modern/report en.pdf

Teare, Peter, A.D. (2006): The Single European Company: Coming of Age?, EU Reporter, 13-14 March

Van Gerven, Dirk - Janssens, Elke (2006): Euro vision, The Lawyer, 20 February http://www.thelawyer.com/cgibin/item.cgi? $\mathrm{id}=118932 \& \mathrm{~d}=11 \& \mathrm{~h}=24 \& \mathrm{f}=23$

Zrzavecky, Jan (2006): SE designation big news for Europe, Czech Business Weekly, 21 April, http://www.cbw.cz/ phprs/2006082123.html 